\title{
Study on ecotourism development in Olele Coastal Area, Bone Bolango Regency, Gorontalo Province
}

\section{Studi pengembangan ekowisata di Kawasan Pesisir Olele, Kabupaten Bone Bolango, Provinsi Gorontalo}

\author{
Moch Machtino A. Mahale ${ }^{1 *}$, Stephanus V. Mandagi ${ }^{2}$, and Markus T. Lasut ${ }^{2}$ \\ ${ }^{1}$ Fakultas Perikanan dan Ilmu Kelautan, Program Studi Magister Ilmu Perairan, Universatas Sam Ratulangi, \\ Jl. Kampus Unsrat Bahu, Manado 951195,Sulawesi Utara, Indonesia. \\ ${ }^{2}$ Fakultas Perikanan dan Ilmu Kelautan, Universitas Sam Ratulangi. Jl. Kampus Unsrat Bahu, \\ Manado 951195, Sulawesi Utara, Indonesia. \\ *E-mail:pepen.m87@gmail.com
}

\begin{abstract}
The purpose of this research is to evaluate coral reef and reef fish condition in coastal waters of Olele village; to study the feasibility of ecotourism development in that area and to formulate ecotourism development strategy. This study reveals that the ecological condition of Olele waters is good, and it was shown by the average coral cover which is higher than $50 \%$. Similarly, fish species is in very high abundance, with a total of 36 species and a total number of more than 12.993 fish, where Pseudanthias tuka is the highest population. In terms of ecotourism feasibility development, total of Pirkins Score were 3,2, and this can be categorized as moderate, meaning that Olele coastal area can be developed as ecotourism area. Finally, strategies for ecotourism development of Olele coastal area are; a) using Olele coastal resources for ecotourism destiny by promoting conservation values, b) infrastructure ecotourism development needs to be improved, c) integratrated ecotourism management policies should be included in policy for development of Kabupaten (disrict) government level; d) development of ecotourism need to cooperation between district government and private sectors.
\end{abstract}

Keywords: coastal management; coral reef; ecotourism; Bone Bolango; Pseudanthias tuka.

\begin{abstract}
Abstrak Tujuan penelitian ini adalah mengevaluasi kondisi terumbu karang dan ikan karang yang berada di perairan pesisir Olele, mengkaji kelayakan pengembangan ekowisata di kawasan pesisir Olele dan merumuskan strategi pengembangan kawasan ekowisata. Dari hasil penelitian dan analisis data, kondisi ekologi perairan Olele berada pada kategori baik: karang pada stasiun 1 rata-rata memiliki tutupan karang hidup $>50 \%$, artinya bahwa keragaman karang tinggi. Sama halnya dengan spesies ikan, jumlah species sebanyak 36 spesies dan total jumlah individu sebanyak 12.993 dimana spesies terbanyak yaitu Pseudanthias tuka. Selanjutnya analisis kelayakan pengembangan ekowisata, total nilai scoring Pirkins 3,2 atau berada pada level moderat, artinya dapat dikembangkan menjadi kawasan ekowisata. Untuk pengembangan ekowisata dikawasan Pesisir Olele, di rekomendasikan beberapa strategi yaitu; a) memanfaatkan sumberdaya pesisir sebagai target utama ekowisata dengan menjunjung nilai-nilai konservasi, b) infrastruktur penunjang pengembangan ekowisata perlu dibenahi, c) perlu dibuat kebijakan pengelolaan dan pengembangan ekowisata secara terpadu antar pemerintah daerah, d) adanya kerja sama antara pemerintah dan pihak swasta dalam hal pengelolaan objek wisata.
\end{abstract}

Kata-kata kunci: pengelolaan pesisir; terumbu karang; ekowisata; Bone Bolangi, Pseudanthias tuka.

\section{PENDAHULUAN}

Pembangunan pariwisata mendorong timbulnya kesadaran untuk mengembangkan pariwisata yang ramah terhadap lingkungan; hal ini merupakan konsep baru dalam pemahaman tentang pariwisata. Konsep baru inilah yang popular dengan sebutan ekowisata. Ekowisata mempunyai kekhususan di mana mengedepankan konservasi lingkungan, pendidikan lingkungan, dan menguntungkan penduduk lokal.

Provinsi Gorontalo memiliki kawasan pesisir yang sangat potensial untuk dikembangkan menjadi kawasan ekowisata, yaitu kawasan Pesisir Olele, di mana daerah tersebut sudah ditetapkan sebagai kawasan konservasi laut daerah (KKLD) dengan bentuk daerah perlindungan laut berbasis masyarakat; berdasarkan SK Bupati Bone Bolango No. 165 Tahun 2006. Potensi terumbu karang 
menjadi salah satu objek daya tarik bagi pengunjung untuk melakukan kegiatan selam ataupun snorkling. Kegiatan ini merupakan bagian dari wisata bahari yang saat ini banyak digemari di Desa Olele.

Untuk mengembangkan Kawasan Pesisir Olele sebagai kawasan ekowisata, maka dibutuhan data dan informasi potensi serta keberadaan sumber daya alam. Hal ini penting, karena menurut Sunyowati (2008), wilayah pesisir dan laut menyimpan sejumlah persoalan yang terkait dengan ekologi, sosial-ekonomi, dan kelembagaan. Sehubungan dengan itu, maka dilakukan penelitian yang mengevaluasi keberadaan aspek ekologi (tutupan karang dan ikan karang); menilai kelayakan berdasarkan variabel potensi sumber daya pesisir Olele, budaya lokal, sosial-ekonomi, infrastruktur kawasan dan institusional; dan merancang strategi pengembangan ekowisata di Kawasan Pesisir Olele.

\section{MATERIAL DAN METODA}

\section{Tempat dan Waktu Penelitian}

Penelitan dilakukan di Desa Olele, Kecamatan Kabila Bone, Kabupaten Bone Bolango. Waktu penelitian berlangsung selama 6 bulan, pada tahun 2014.

\section{Pengumpulan Data}

Pengelompokan data yang dikumpulkan bersumber dari data primer dan data sakunder. Pengumpulan data primer, yang menunjang penelitian, diperoleh melalui hasil survei atau observasi, dan wawancara (menggunakan kuesioner) secara langsung dengan sumber yang didapat melalui rensponden atau stakeholder yang terkait.

Pengamatan terhadap tutupan karang menggunakan metode PIT (Point Intercept Transect) dengan 3 stasiun pada kedalaman $5 \mathrm{~m}$ dan $10 \mathrm{~m}$. Untuk pengamatan Ikan karang menggunakan metode "sensus visual"; pengamatan dilakukan sepanjang transek $100 \mathrm{~m}$ dengan jarak 2,5 m ke kiri dan 2,5 m ke kanan dengan luas kawasan $500 \mathrm{~m}^{2}$.

Kuesioner terdiri dari 100 orang responden, yang berasal dari masyarakat Desa Olele. Pengambilan sampel berdasarkan purposive sampling, yaitu pengambilan sampling berdasarkan pertimbangan tertentu (Sugiyono, 2012). Selain itu, melakukan wawancara secara mendalam kepada stakeholder terkait. Untuk kuesioner pada wisatawan lokal, terdiri dari 25 responden dengan metode random sampling di mana setiap pengunjung yang datang dilokasi penelitian dijadikan sebagai responden.

Data sekunder dikumpulkan dan diperoleh melalui kajian literatur dan dokumentasi yang berasal dari tulisan-tulisan ilmiah, data statistik desa, Dinas Perikanan dan Kelautan Provinsi dan Kabupaten Bone Bolango, Dinas Pariwisata Provinsi Gorontalo, diving center, dan instansi terkait lainnya.

\section{Analisis Data}

Untuk mengindentifikasi tutupan karang dilakukan dengan metode PIT (Point Intercept Transect). Data pengamatan selanjutnya dianalisa dengan rumus sederhana, sebagai berikut :

$$
\text { Persentasi tutupan }=\frac{\text { Jumlah Titik Tiap Komponen }}{\text { Total Komponen }} \times 100 \%
$$

Analisis ikan di identifikasi dengan menggunakan Buku Panduan Monitoring Terumbu Karang - Reef Check.

Scoring dipakai untuk menentukan tingkat kelayakan dalam pengembangan ekowisata, pembobotan berdasarkan pengamatan untuk setiap parameter dari aspek potensi sumberdaya alam, budaya lokal, sosial-ekonomi masyarakat lokal, infrastruktur kawasan, dan Institusional dengan mengikuti panduan Lintong (2010).

Pemboboton terdiri atas lima level, yang terdiri dari atas level 1, 2, 3, 4, dan 5). Level 1 bermakna poor atau miskin, level 2 (bermakna moderate to poor atau mendekati miskin). Level 1 dan 2 dikatagorikan rendah, yang berarti potensi berada pada kondisi yang tidak dimungkinkan untuk dikembangkan. Level 3 bermakna moderat, yang berarti potensi berada pada kondisi seadanya, tapi masih bisa dikembangkan dengan perlakuanperlakuan tertentu. Level 4 (bermakna moderate to good atau mendekati baik), dan level 5 (bermakna good atau baik). Level 4 dan 5 dikategorikan tinggi, yang berarti potensi memungkinkan untuk dikembangkan (Priskin, 2001)

$$
\text { Analisis matriks SWOT (Strength, }
$$

Weakness, Opportunity, Treaths) dipakai untuk 
merancang strategi pengembangan ekowisata di Kawasan Pesisir Olele di mana penggunaanya untuk mengetahui gambaran tentang kekuatan, kelemahan, peluang, dan ancaman yang dihadapi dalam pengembangan ekowisata di Pesisir Olele. Setelah itu, dirumuskan rancangan strategi yang tepat untuk direkomendasikan bagi pengembangan Kawasan Pesisir Olele sebagai suatu kawasan ekowisata. Rangkuti (2013) menjelaskan, bahwa dalam menyusun formulasi strategis disusun dengan menggunakan hasil analisis SWOT dengan menggabungkan berbagai indikator yang terdapat dalam kekuatan, kelemahan, peluang, dan ancaman. Strategi yang dipilih adalah strategi yang dapat memecahkan isu strategis dalam pengembangan ekowisata di Pesisir Olele.

\section{HASIL DAN PEMBAHASAN}

\section{Evaluasi Kondisi Karang dan Ikan Karang di Perairan Pesisir Olele}

Tutupan karang yang berada di Pesisir Olele, berdasarkan hasil pengamatan di 3 stasiun pada kedalaman $5 \mathrm{~m}$ dan $10 \mathrm{~m}$, ditampilkan dalam Tabel 1.

Berdasarkan Kepmeneg LH. No. 4, tahun 2001, tentang Kriteria Baku Kerusakan Terumbu Karang, pengamatan pada Stasiun 1, menunjukkan persentasi tutupan karang hidup pada kedalaman 5 m sebesar $63,75 \%$, dalam kategori "baik", dan pada kedalaman $10 \mathrm{~m}$ sebesar 76,88\%, berarti dalam kategori "baik sekali". Stasiun 1 ini merupakan salah satu spot diving yang berada pada pesisir Desa Olele. Pada Stasiun 2, berdasarkan hasil pengamatan pada kedalaman $5 \mathrm{~m}$ tutupan karang sebesar 43,13\% masuk dalam kategori "sedang"; sedangkan pada kedalaman $10 \mathrm{~m}$, tutupan karang sebesar 50, 63 \%, masuk dalam kategori "baik". Pada Stasiun 3, berdasarkan hasil pengamatan pada kedalaman $5 \mathrm{~m}$, tutupan karang sebesar 35,63\%, masuk dalam kategori 'sedang'; sedangkan pada kedalaman $10 \mathrm{~m}$, tutupan karang sebesar 43,13\%, masuk dalam kategori "sedang".

Hasil dari pengamatan ikan karang, yaitu pada Stasiun 1, di kedalaman $5 \mathrm{~m}$, terdapat 23 spesies dengan total individu 2807 ekor dan di kedalaman $10 \mathrm{~m}$, terdapat 16 spesies dengan total individu 995 ekor. Pada Stasiun 2, kedalaman 5 m, terdapat 9 spesies dengan total individu 3720 ekor dan di kedalaman $10 \mathrm{~m}$, terdapat spesies 9 spesies dengan total individu 2401 ekor. Pada Stasiun 3, di kedalaman $5 \mathrm{~m}$ terdapat 16 spesies dengan total individu 901 ekor, dan pada kedalaman $10 \mathrm{~m}$, terdapat 18 spesies dengan total individu 2139 ekor. Jumlah total spesies 36 dan jumlah total individu sebanyak 12.993 (Tabel 2).

\section{Kelayakan Pengembangan Ekowisata}

Kelayakan pengembangan ekowisata dianalisis menggunakan scoring dengan variabel pengamatan, antara lain, potensi sumber daya alam, budaya lokal, sosial ekonomi, infrastruktur kawasan, dan kelembagaan. Berdasarkan hasil wawancara, pengamatan, dan survey langsung, setelah diberi bobot terhadap variabel-variabel kategori penilaian potensi ekowisata, maka diperoleh hasil pembobotan. Tingkat kelayakan Kawasan Pesisir Olele memperoleh skor 3,2, artinya berada pada level moderat. Priskin (2001) menyatakan, bahwa suatu kawasan menjadi potensial dikembangkan sebagai objek wisata alam bila memiliki komponen-komponen potensial untuk dijaga dan dikembangkan.

\section{Potensi Sumberdaya Alam}

Selain terumbu karang, potensi sumber daya pesisir yang menjadi objek daya tarik wisatawan adalah "Goa Jin", yang di dalamnya terdapat biota atraktif seperti orangutan crab, colemani shrimp, soft coral crab, sarasvati shrimp, lionfish dan bermacam-macam nudibranch (Allen, 2014). Potensi lainnya, berupa salvador dali yang

Tabel 1. Persentasi Tutupan Karang di Kawasan Pesisir Olele

\begin{tabular}{lllllll}
\hline \multirow{2}{*}{ Persentasi tutupan karang } & \multicolumn{2}{c}{ Stasiun 1} & \multicolumn{3}{c}{ Stasiun 2} & \multicolumn{3}{c}{ Stasiun 3} \\
\cline { 2 - 7 } & $5 \mathrm{~m}$ & $10 \mathrm{~m}$ & $5 \mathrm{~m}$ & $10 \mathrm{~m}$ & $5 \mathrm{~m}$ & $10 \mathrm{~m}$ \\
\hline karang keras & 56,25 & 73,75 & 43,13 & 50,63 & 35,63 & 42,50 \\
karang lunak & 7,50 & 3,13 & - & - & - & 0,63 \\
sponge & 0,63 & 1,88 & 6,88 & 33,13 & 1,25 & 2,50 \\
batuan & - & 1,25 & & 0,63 & 40,00 & 37,50 \\
lainnya & 0,63 & 0,63 & 0,63 & 0,63 & - & - \\
\hline
\end{tabular}


pinggirannya menyerupai lukisan "Salvador Dali", yang menjadi daya tarik penyelam di Taman Bawah Laut Olele. Selain itu, terdapat juga biota aktratif lainnya, seperti lumba-lumba, pari, dan hiu karang, namun biota tersebut tidak sering dijumpai.

Selain potensi yang ada di wilayah bawah laut, potensi yang ada di daratan pesisir Desa Olele bisa dijadikan sebagai objek daya tarik wisata daratan pesisir Olele, yang berupa pantai berbatu dan pantai berpasir.

\section{Budaya Lokal}

Berdasarkan hasil wawancara, di Desa Olele tidak ada kerarifan lokal, yang ada hanyalah atraksi budaya lokal. Atraksi budaya lokal, seperti "buruda" dan "tolakbala", tidak lagi rutin

Tabel 2. Hasil Pengamatan Ikan Karang Pada Perairan Pesisir Olele

\begin{tabular}{|c|c|c|c|c|c|c|c|c|c|c|c|c|c|c|}
\hline \multirow{2}{*}{ No } & \multirow{2}{*}{ Jenis Ikan Karang } & \multicolumn{4}{|c|}{ Stasiun 1} & \multicolumn{4}{|c|}{ Stasiun 2} & \multicolumn{4}{|c|}{ Stasiun 3} & \multirow[t]{2}{*}{ Total } \\
\hline & & $5 \mathrm{~m}$ & $\Sigma$ & $10 \mathrm{~m}$ & $\sum$ & $5 \mathrm{~m}$ & $\Sigma$ & $10 \mathrm{~m}$ & $\Sigma$ & $5 \mathrm{~m}$ & $\sum$ & $10 \mathrm{~m}$ & $\sum$ & \\
\hline 1 & Acanthurus leuchocheilus & $\sqrt{ }$ & 120 & $\sqrt{ }$ & 50 & - & - & - & - & $\sqrt{ }$ & 13 & - & - & 183 \\
\hline 2 & Acanthurus nubilus & $\sqrt{ }$ & 40 & - & - & - & - & - & - & - & - & $\sqrt{ }$ & 50 & 90 \\
\hline 3 & Ambligliphydodon aureus & $\sqrt{ }$ & 45 & $\sqrt{ }$ & 170 & $\sqrt{ }$ & 310 & - & - & - & - & - & - & 525 \\
\hline 4 & $\begin{array}{l}\text { Amblygliphidodon curacao } \\
\text { Amblygliphidodon }\end{array}$ & - & - & - & - & $\sqrt{ }$ & 60 & $\sqrt{ }$ & 50 & - & - & $\sqrt{ }$ & 50 & 160 \\
\hline 5 & leucogaster & - & - & - & - & - & - & - & - & $\sqrt{ }$ & 40 & $\sqrt{ }$ & 126 & 166 \\
\hline 6 & Amphiprion melanopus & - & - & - & - & - & - & - & - & $\sqrt{ }$ & 11 & - & - & 11 \\
\hline 7 & Chaetodon baronessa & $\sqrt{ }$ & 34 & $\sqrt{ }$ & 10 & - & - & - & - & - & - & $\sqrt{ }$ & 25 & 69 \\
\hline 8 & $\begin{array}{l}\text { Chaetodon klenii } \\
\text { Chaetodon }\end{array}$ & - & - & - & - & - & - & $\sqrt{ }$ & 500 & - & - & $\sqrt{ }$ & 54 & 554 \\
\hline 9 & punctatofasciatus & $\sqrt{ }$ & 30 & $\sqrt{ }$ & 40 & - & - & $\sqrt{ }$ & 26 & - & - & - & - & 96 \\
\hline 10 & Cheillinus undulatus & $\sqrt{ }$ & 1 & - & - & - & - & - & - & - & - & - & - & 1 \\
\hline 11 & Chlorurus bleekeri & $\sqrt{ }$ & 38 & $\sqrt{ }$ & 58 & - & - & - & - & - & - & - & - & 96 \\
\hline 12 & Chromis amboinensis & $\sqrt{ }$ & 80 & $\sqrt{ }$ & 60 & $\sqrt{ }$ & 400 & - & - & $\sqrt{ }$ & 40 & - & - & 580 \\
\hline 13 & Chromis margaritifer & $\sqrt{ }$ & 200 & $\sqrt{ }$ & 60 & - & - & $\sqrt{ }$ & 300 & - & - & - & - & 560 \\
\hline 14 & Chromis ternatensis & $\sqrt{ }$ & 400 & - & - & - & - & - & - & - & - & $\sqrt{ }$ & 200 & 600 \\
\hline 15 & Chromis xanthura & - & - & - & - & - & - & - & - & $\sqrt{ }$ & 160 & $\sqrt{ }$ & 320 & 480 \\
\hline 16 & Chrysiptera rolandi & - & - & - & - & - & - & - & - & - & - & $\sqrt{ }$ & 100 & 100 \\
\hline 17 & Chrysiptera talboti & - & - & - & - & - & - & - & - & $\sqrt{ }$ & 60 & - & - & 60 \\
\hline 18 & Cirhillabrus sp. & - & - & - & - & - & - & - & - & - & - & $\sqrt{ }$ & 80 & 80 \\
\hline 19 & Dascyllus reticulatus & - & - & - & - & - & - & - & - & $\sqrt{ }$ & 100 & - & - & 100 \\
\hline 20 & Dascylus trimaculatus & - & - & - & - & - & - & - & - & - & - & $\sqrt{ }$ & 30 & 30 \\
\hline 21 & Forcipiger flavissimus & $\sqrt{ }$ & 14 & $\sqrt{ }$ & 21 & - & - & - & - & $\sqrt{ }$ & 12 & $\sqrt{ }$ & 22 & 69 \\
\hline 22 & Hemitaurichthys polylepis & - & - & $\sqrt{ }$ & 70 & $\sqrt{ }$ & 50 & $\sqrt{ }$ & 300 & - & - & - & - & 420 \\
\hline 23 & Heniochus varius & $\sqrt{ }$ & 2 & - & - & - & - & - & - & $\sqrt{ }$ & 20 & $\sqrt{ }$ & 22 & 44 \\
\hline 24 & Monotaxis granduculis & $\sqrt{ }$ & 14 & $\sqrt{ }$ & 13 & - & - & $\sqrt{ }$ & 25 & - & - & - & - & 52 \\
\hline 25 & Naso lituratus & $\sqrt{ }$ & 35 & $\sqrt{ }$ & 20 & - & - & - & - & $\sqrt{ }$ & 38 & - & - & 93 \\
\hline 26 & Neoglyphidodon nigroris & $\sqrt{ }$ & 104 & $\sqrt{ }$ & 80 & $\sqrt{ }$ & 550 & $\sqrt{ }$ & 200 & $\sqrt{ }$ & 35 & - & - & 969 \\
\hline 27 & Platax boersii & $\sqrt{ }$ & 4 & $\sqrt{ }$ & 12 & - & - & - & - & - & - & - & - & 16 \\
\hline 28 & Plectroglyphidodon dickii & $\sqrt{ }$ & 30 & - & - & $\sqrt{ }$ & 450 & $\sqrt{ }$ & 500 & $\sqrt{ }$ & 20 & $\sqrt{ }$ & 50 & 1050 \\
\hline 29 & Pomacentrus amboinensis & - & - & - & - & - & - & - & - & $\sqrt{ }$ & 250 & $\sqrt{ }$ & 410 & 660 \\
\hline 30 & Pomacentrus coelstis & - & - & - & - & - & - & - & - & - & - & $\sqrt{ }$ & 200 & 200 \\
\hline 31 & Pomacentrus mollucensis & $\sqrt{ }$ & 350 & $\sqrt{ }$ & 285 & $\sqrt{ }$ & 400 & - & - & - & - & $\sqrt{ }$ & 100 & 1135 \\
\hline 32 & Pseudanthias bicolor & $\sqrt{ }$ & 200 & - & - & $\sqrt{ }$ & 700 & - & - & - & - & - & - & 900 \\
\hline 33 & Pseudanthias tuka & $\sqrt{ }$ & 1000 & - & - & $\sqrt{ }$ & 800 & $\sqrt{ }$ & 500 & $\sqrt{ }$ & 80 & $\sqrt{ }$ & 300 & 2680 \\
\hline 34 & Scarus hypselopterus & $\sqrt{ }$ & 52 & $\sqrt{ }$ & 30 & - & - & - & - & - & - & - & - & 82 \\
\hline 35 & Siganus guttatus & $\sqrt{ }$ & 2 & $\sqrt{ }$ & 16 & - & - & - & - & $\sqrt{ }$ & 12 & - & - & 30 \\
\hline 36 & Zanclus cornutus & $\sqrt{ }$ & 12 & - & - & - & - & - & - & $\sqrt{ }$ & 10 & $\sqrt{ }$ & 30 & 52 \\
\hline & Total Spesies & 23 & & 16 & & 9 & & 9 & & 16 & & 18 & & \\
\hline & Total Individu & 2807 & & 995 & & 3720 & & 2401 & & 901 & & 2169 & & 12.993 \\
\hline
\end{tabular}


dilaksanakan. Hanya atraksi budaya "tolakbala", yang biasanya dibuat pada tanggal 10 Muharam; kegiatan tersebut masih rutin dilakukan. Menurut Mangindaan (2012), budaya lokal ini, bersama dengan potensi sumber daya alam, merupakan aspek penting dalam pengembangan ekowisata. Dengan demikian, atraksi budaya, kearifan lokal, dan produk kerajinan tangan di Desa Olele bisa dikembangkan dalam produk dan aset utama pada industri ekowisata secara bersamaan dengan komponen sumber daya alam. Namun, hal ini dipengaruhi oleh faktor keterlibatan masyarakat lokal akan pertunjukan seni dan budaya di mana masih 'sangat kurang'. Dari hasil wawancara kepada 100 orang responden, hanya $10 \%$ masyarakat lokal yang "sering terlibat", $41 \%$ "jarang terlibat", dan $49 \%$ tidak pernah terlibat (Gambar 1).

\section{Sosial-Ekonomi Masyarakat Lokal}

Dalam pengembangan kawasan ekowisata di Desa Olele, pemahaman masyarakat lokal terhadap ekowisata dan keterlibatan masyarakat lokal terhadap program-program pengembangan sebagai kawasan ekowisata sangatlah penting. Hasil survei dan wawancara pada 100 orang responden menunjukkan, bahwa sebanyak $62 \%$ "tidak mengetahui" maksud dan tujuan ekowisata, dan $38 \%$ "mengetahui" apa itu ekowisata seperti yang ditunjukan pada Gambar 2.

\section{Infrastruktur Kawasan}

Menurut Nugroho (2010), pembangunan infrastruktur dan fisik penting bagi pengembangan wilayah ekowisata. Infrastruktur perlu mencerminkan nilai-nilai konservasi, best practice, dan lanskap, tetapi juga membantu pemahaman budaya dan akses ke seremoni tradisi, dan kehidupan kemasyarakatan atau pengalaman lokal. Layanan dan akomodasi terbaik bagi pengunjung harus diseratai dengan upaya dalam minimasi dampak negatif.

Akses menuju ke kawasan ini bisa melalui transportasi darat dan laut. Dari pusat kota membutuhkan waktu sekitar 30-40 menit melalui jalan darat. Kondisi jalan menuju ke pintu gerbang masuk ke Desa Olele dalam keadaan "baik". Namun, jalan akses ke perkampungan Desa Olele dalam kondisi "sedang" dan "rusak". Sebagian merupakan jalan aspal yang berlubang dan sebagian lagi tanah.

Fasilitas untuk potensi pengembangan pariwisata dengan konsep ekowisata masih dalam kategori "sedang". Fasilitas wisatawan yang banyak dijumpai di kawasan pesisir olele, pada umumnya, berupa perahu katamaran. Perahu katamaran ini dilengkapi dengan kaca bawah air, sehingga wisatawan bisa melihat keindahan karang dan ikan dari atas perahu.

Fasilitas lainnya, yang masih perlu dibenahi, yaitu tempat sampah. Sampah menjadi salah satu masalah yang ada di pesisir Olele. Selain itu, fasilitas listrik, komunikasi, ketersediaan air bersih, cukup baik; demikian halnya tempat makan, kios-kios bisa dijumpai di desa ini. Rumah-rumah masyarakat sering digunakan sebagai homestay bagi wisatawan yang ingin tinggal lebih lama.

\section{Kelembagaan}

Deskripsi aspek kelembagaan dilakukan pada dua sub-aspek, yaitu regulasi dan organisasi. Organisasi adalah kelompok masyarakat yang berinteraksi dalam kawasan dan berkaitan erat dengan pengembangan ekowisata. Regulasi adalah semua aturan yang diberlakukan dalam kawasan yang berhubungan erat dengan ekowisata, aturan tersebut bisa berbentuk aturan tertulis atau aturan tidak tertulis seperti hukum adat dan kesepakatan bersama (Lintong, 2010).

Pada aspek Organisasi, berdasarkan hasil

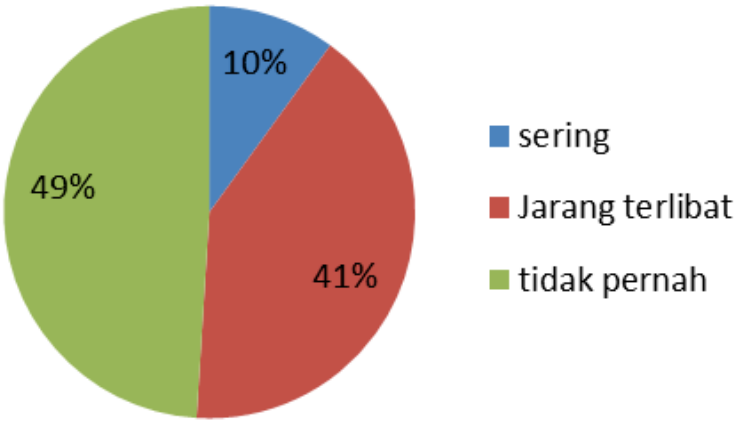

Gambar 1. Keterlibatan Masyarakat Lokal dalam kegiatan seni dan budaya

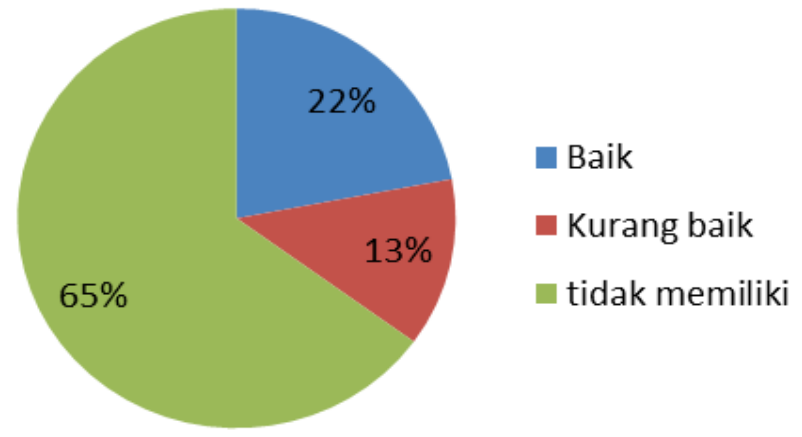

Gambar 2. Responden Yang Memiliki Keterampilan Tangan 
pengamatan dan wawancara, bahwa di kawasan pesisisr Olele belum ada organisasi, baik formal maupun informal, yang berkaitan langsung dengan wisata, apalagi dalam pengembangan ekowsiata. Organisasi yang dijumpai di desa hanyalah kelompok pengawasan Kawasan Konservasi Laut Daerah. Untuk tingkat wilayah, belum ada kelembagaan ataupun organisasi yang dibentuk oleh Pemerintah Kabupaten Bone Bolango ataupun Provinsi Gorontalo untuk pengembangan ekowisata. Pemerintah daerah hanya melakukan monitoring dan pengawasan terhadap aktivitasaktivitas yang merusak di kawasan konservasi laut daerah.

Pada aspek regulasi, pembentukan Kawasan Konservasi Laut Daerah tertuang dalam Surat Keputusan Bupati No. 165 Tahun 2006. Aturan ini mengatur pengelolaan kawasan konservasi laut daerah. Zonasi ditetapkan dengan Peraturan Desa No. 01/Perdes/d-ol/kb-bb/xi-2006.

\section{Rancangan Strategi Pengembangan Ekowisata}

Strategi pengembangan Kawasan Pesisir

Olele sebagai Kawasan ekowisata, berdasarkan Analisis SWOT, terdiri dari:

1. Potensi sumber daya pesisir (karang, ikan, dan biota lainnya) dapat dijadikan tujuan/target pengembangan ekowisata.

2. Infrastruktur, sebagai penunjang pengembangan ekowisata, perlu diperbaiki dan dibangun.

3. Perlu dibuat kebijakan pengelolaan dan pengembangan ekowisata secara terpadu, yaitu memerlukan keterpaduan program antar lintas sektoral di dalam pemerintahan daerah untuk saling mendukung dalam pengembangan ekowisata sebagai salah satu kebijakan strategis.

4. Perlu ditingkatkan kerjasama antara pemerintah dan pihak swasta dalam pengelolaan objek wisata yang ada di Pesisir Desa Olele.

\section{KESIMPULAN}

Dari penelitian yang dilakukan, maka dapat disimpulkan sebagai berikut:

1. Presentasi tutupan karang hidup di Desa Olele adalah besar $50 \%$, artinya dalam kondisi baik. Jumlah spesies ikan yang ditemukan di perairan pesisir Olele adalah sebanyak 36 spesies dan spesies ikan karang yang paling banyak adalah Pseudanthias tuka.

2. Kawasan Pesisir Olele layak dikembangkan dengan memaksimalkan potensi yang ada dan membenahi faktor-faktor yang mempengaruhi kelayakan di daerah tersebut.

3. Strategi yang dapat digunakan dalam pengembangan ekowisata di kawasan Pesisir Olele adalah: a) potensi sumber daya pesisir dapat dijadikan tujuan/target ekowisata; b) infrastruktur penunjang pengembangan ekowisata perlu dibenahi; c) perlu dibuat kebijakan pengelolaan dan pengembangan ekowisata secara terpadu; d) adanya kerjasama antara pemerintah dan pihak swasta dalam hal pengelolaan objek wisata.

\section{REFERENSI}

ALLEN, R. (2014) Goa Jin-Gorontalo Dive Site Yang Misterius. http://miguelsdiving. com/blog/2014/12/20/goa-jin-gorontalo/. Diakses 22 Mei 2017.

LINTONG, O. (2010) Potensi Ekowisata Di Kawasan Pesisir Arakan-Wawontulap Provinsi Sulawesi Utara. Tesis. Manado: Program Pascasarjana Universitas Sam Ratulangi. Manado. Tidak dipublikasikan.

NUGROHO, I. (2011) Ekowisata dan Pembangunan Berkelanjutan. Yogyakarta: Pustaka Belajar.

PRISKIN, J. (2001) Assessment Of Natural Resource For Nature-Based Tourism: The Case of The Central Coast Region of Western Australia. Tourism Management Journal, 22, 634-648.

RANGKUTI, F. (2013) SWOT Balanced Scorecard: Teknik Menyusun Strategi Korporat yang Efektif Plus Cara Mengelola Kinerja dan Resiko. Jakarta: PT Gramedia Pusataka Utama.

SUGIYONO (2012) Metode Penelitian Kombinasi (Mixed Methods). Bandung: Alfabeta.

SUNYOWATI, D. (2008) Penataan Ruang Laut Berdasarkan Integrated Coastal Management. Mimbar Hukum, 20(3), 411-588.

Received: 5 May 2018 Accepted: 25 July 2018 